\title{
OCCUPATIONAL SEGREGATION AND THE GENDER WAGE GAP IN BRAZIL: AN EMPIRICAL ANALYSIS*
}

\author{
Regina Madalozzo ${ }^{\dagger}$
}

\begin{abstract}
Several countries experienced an increase in female labor participation during the twentieth century. Even so, few can be proud of the conditions female workers faced. This paper analyzes the occupational distribution by gender from 1978 to in 2007 in Brazil. It shows that women have penetrated traditionally male occupations to a certain extent, but that traditionally female occupations have maintained their gender composition over the past 30 years. We also provide a regression analysis with an Oaxaca decomposition that shows that the gender wage gap is lower than in 1978 , but that it has remained constant over the last decade.
\end{abstract}

Keywords: wage differentials, discrimination, and female labor market.

Palavras-chave: diferenciais de salário, discriminação, mercado de trabalho feminino

JEL classification: J24, J31, J71.

\section{Introduction}

Virtually all countries experienced an increase in female labor participation during the twentieth century. Even so, few can be proud of the conditions that female workers face in dealing with family responsibilities and the labor market. The division of labor within families continues to fall along traditional gender lines, even when women engage in labor market activities. Women who are engaged in the labor market are still expected to be available to comply with their family responsibilities of housework, childcare and other activities (Hersch \& Stratton 1994, Alvarez et al. 2006, Lundberg 2008, Madalozzo et al. 2008, Gupta \& Ash 2008). Further, women continue to receive lower wages than men, even when controlling for personal characteristics and job attributes (Blau \& Kahn 1997, Bertrand \& Hallock 2001, Albrecht et al. 2003, Bayard et al. 2003, Bucheli \& Sanroman 2005, Galarza et al. 2006, Madalozzo \& Martins 2007, Olivetti \& Petrongolo 2008). There is no consensus among specialists as to whether a gendered division of labor at home causes the wage gap or vice versa. However, the majority of studies agree that some intrinsic

\footnotetext{
* This paper has benefited from the suggestions made by an anonymous referee and the excellent research assistance of Carolina Flores Gomes. The research was conducted with financial support from CNPq (Productivity Research Fellowship \#307513/2007-6)

† Insper Instituto de Ensino e Pesquisa, email:reginam@insper.edu.br
} 
features of gender have a significant influence on these outcomes of a lower wage and second shift.

One possibility is that the career interruptions that women experience during their reproductive life ${ }^{1}$ make them less productive on the labor market and, therefore, available to work for lower wage rates (Deloach \& Hoffman 2002, Hersch \& Stratton 2002, Moe 2003, Blau et al. 2006, Bryan \& Sanz 2007). Another possibility is that women's wages are lower because they account for benefits that are available only to women, for example, maternity leave (Waldfogel 1998, Edwards 2006, Bergmann 2008). As a final point, another possibility is that women choose to work in occupations and activities with lower remuneration than those chosen by men (Easterlin 1995, Macpherson \& Hirsch 1995, Miller 2009). Any of these possibilities may impact - or be impacted by - the gender division of labor by making it less costly to the household for women to spend more hours at home instead of men; if both spouses are equally productive to the market, but the husband receives higher remuneration for his work than his wife, he has a comparative advantage in dedicating more time and effort to the market (Ferber 2003).

Our focus in this study is to analyze female labor participation in Brazil since the 1970s. Brazil is a highly unequal country in several aspects. It has one of the worst Gini indexes in the world, 0.567, and had the 10th worst income distribution in the world in 2007. Concerning gender differences, Brazil ranked 74th out of 127 countries in the 2007 World Economic Forum's Gender Gap index, with a score of $0.664 .^{2}$ Using data from 1978 to 2007 will allow us to understand two different problems related to women's labor participation: occupational segregation and the gender wage gap over time.

Female labor participation in Brazil increased substantially during the second half of the twentieth century, as depicted in Figure 1. In 1950, roughly 14 percent of females participated in the labor market. By 1980, this number had nearly doubled to 27 percent. The 1980 s was the decade that witnessed the biggest inclusion of women in the labor market and by 1992, 47 percent of women were engaged in some economic activity or were seeking work. Since them, female inclusion in the labor market has slowly continued to grow. In 2007, 52.4 percent of women were economically active. Nevertheless, women's working conditions in the labor market and within their households has remained inequitable.

Other studies have analyzed labor market conditions for women in Brazil. Bruschini $(1989,1998)$ reported the trends for the female labor market regarding insertion and intermittency. The present research continues these analyses into the new century. In addition, we use econometric resources to evaluate female entries into industry and occupations and to compare female and male wages, controlling for individual characteristics. Giuberti \& Menezes-Filho (2005), Jacinto (2005) and Batista \& Cacciamali (2009) all used the Oaxaca-Blinder methodology to compare earning differentials between men and women, though each of these studies had a different focus. ${ }^{3}$ Com-

\footnotetext{
${ }^{1}$ Labor intermittency caused by marriage, childbirth or other family needs involving the woman.

${ }^{2}$ Where one represents complete equal treatment between genders and zero, total inequality. The gender gap index considers four dimensions: economic participation and opportunity, educational attainment, health and survival, and political empowerment.

${ }^{3}$ Garcia et al. (2009) use the matching approach to infer the gender wage gap. Their results are very similar to those reported in this study.
} 


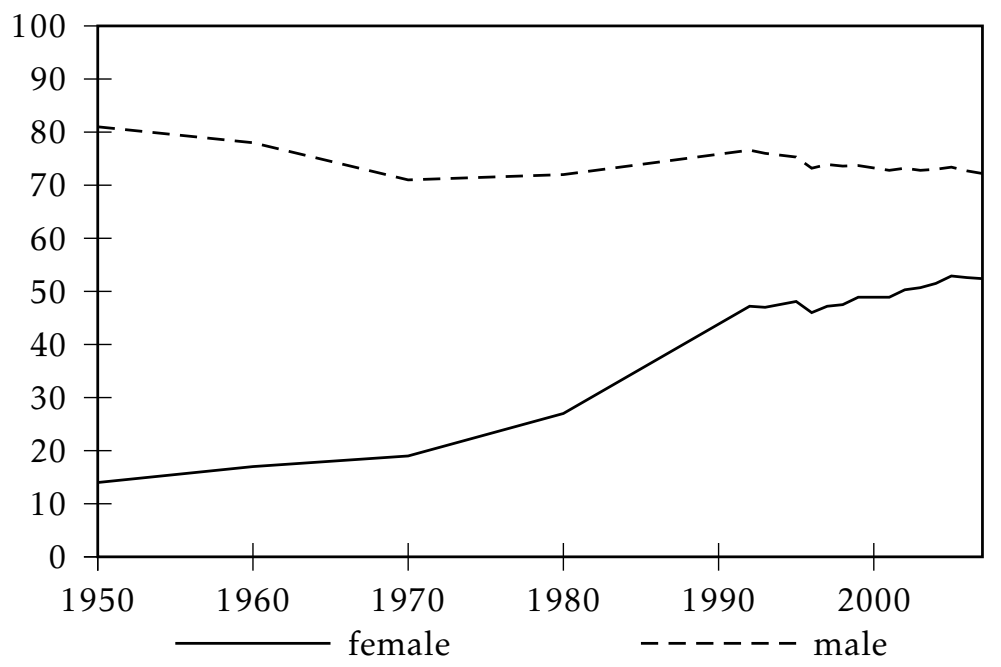

Source: IBGE, Estatísticas do Século XX

Figure 1: Labor Market Participation. Male and Female, 19502007.

plementing their work, we expanded the period analyzed and emphasized the role of occupation choice in wage profiles. Our analyses target the average differences in labor market earnings for men and women for the period between 1978 and 2007. Finally, Scorzafave \& Pazello (2007) also studied the gender wage gap in Brazil, however their goal was to apply normalized equations to solve the indetermination problem of the Oaxaca-Blinder decomposition approach. We use their methodology in our research to better understand the impact of the occupation transition process on narrowing the gender wage gap during this period. ${ }^{4}$

This paper is organized as follows: in the next section we describe Brazilian labor characteristics, focusing on activities and gender differentials. Section 3 explains the empirical model used to analyze the gender gap in remuneration and the impact of occupational differentials. The results are presented in Section 4. Section 5 offers conclusions.

\section{The Brazilian labor market: are there gender differences?}

In this section, we describe Brazilian labor markets and highlight the differences and similarities between genders with regard to them. Before entering into such a discussion, however, it is necessary to explain some peculiarities of the Brazilian labor market. First, it is highly regulated. Since the 1930s, with the implementation of the first laws concerning employment in Brazil, there have been an increased number of restrictions and fees employers must pay to be able to hire individuals. The constitution of 1988 aggravated this problem. Second, women have gained specific rights to maternity leave. Before 1988, all female workers had the right to a fully paid maternity leave of 90 days. The new constitution increased this right to 120 days. In 2007,

\footnotetext{
${ }^{4}$ By no means do these cited studies cover the entire body of literature on the gender wage gap in Brazil. However, the studies presented here are closely related to the goals and methods of this paper.
} 
new federal legislation was passed in response to the World Health Organization's recommendation that babies should be breastfed for 6 months. Under this law, female workers may opt to take 6 months of maternity leave, also fully paid by the employer. ${ }^{5}$ These stringent regulations on the labor market are the concern of many researchers, who question their ability to guarantee workers' rights by suggesting that such regulations may force workers into informal jobs, where they will have no rights at all.

Our analysis used microdata from PNAD (Pesquisa Nacional de Amostra por Domicilios, which translates to National Survey of Sampled Households). PNAD is an annual survey conducted by the Brazilian Bureau of Statistics, IBGE. It takes a representative sample of Brazilian households and studies, among other aspects of the population, labor, education and health. It contains data at an individual level for the sampled dwellings. Since 2004, PNAD has investigated data for all national territory. ${ }^{6}$ With the purpose of analyzing the past and current employment trends, we used data from four different decades: 1978, 1988, 1998, and 2007, the most recent data released by IBGE. Questionnaires were modified during this period; however, we made some concatenations in order to make them comparable.

Table 1 presents the female distribution among different occupation categories. $^{7}$ For each year, we divided the occupations into traditionally male or traditionally female. ${ }^{8}$ It can be observed that the majority of occupations remain majority male over time (for example, carpenters, mechanics, drivers, etc.), while others maintain their tendency to be female-dominated occupations (including nurses, librarians, and schoolteachers). Nevertheless, some changes are visible. While in 1978 only 4.94 percent of engineers were women, in 2007 more than 10 percent of engineers were female. This is still a small number of individuals; however, it establishes a change in pattern. Other examples of traditionally male occupations that are being occupied by increasing numbers women are insurance agents, police and detectives, and managers and administrators.

On the other side, traditionally female occupations rarely present such a change. There are a few possible explanations for this phenomenon. The first is that men resist engaging in activities that are regarded as "female." This would reflect gender preferences for certain activities and against others. Historically, women engaged in market activities closely related to their domestic work (Folbre 1994). Considering that men have historically been distant from such work, it is plausible to infer that males would prefer a different type of activity and, therefore, favor traditionally male occupations.It may also be the case that this difference is related to worker discrimination (Kaufman \& Hotchkiss 2003). This would be the case if men charged a premium to work

\footnotetext{
${ }^{5} \mathrm{Up}$ to a ceiling of 12 thousand Reais, maternity leave is paid by the employer who is reimbursed by the government in taxes. This is a very high ceiling. Less than 3 percent of female workers earn more than this value monthly.

${ }^{6}$ Until then, 1.9 percent of the Brazilian population was not included in the sample because they lived in areas not researched. However, the analysis contains weights that allow for comparison with earlier years.

${ }^{7}$ This table was inspired by Table 8.3, in Kaufman \& Hotchkiss (2003, p.425).

${ }^{8}$ It may be pointed out that there is a very high level variation in the number of individuals in some categories. For instance, the number of individuals that claim to be economists in 2007 is well above the expected increase in the population. However, the result is conditional on the individual weight assigned to the population. Even when the weight is corrected for individual characteristics, it may still distort individual data, such as occupation.
} 
Table 1: Percentage of females in traditionally male and traditionally female occupations.

\begin{tabular}{|c|c|c|c|c|}
\hline \multicolumn{5}{|c|}{ Traditionally Male Occupations } \\
\hline Occupation & 1978 & 1988 & 1998 & 2007 \\
\hline Engineers & $\begin{array}{c}4.94 \\
{[4,778]}\end{array}$ & $\begin{array}{l}2.47 \\
{[455]}\end{array}$ & $\begin{array}{c}8.35 \\
{[15,682]}\end{array}$ & $\begin{array}{c}10.08 \\
{[29,382]}\end{array}$ \\
\hline Lawyers & $\begin{array}{c}18.18 \\
{[15,386]}\end{array}$ & $\begin{array}{l}25.86 \\
{[3,708]}\end{array}$ & $\begin{array}{c}38.40 \\
{[104,003]}\end{array}$ & $\begin{array}{c}43.86 \\
{[207,225]}\end{array}$ \\
\hline Physicians & $\begin{array}{c}18.29 \\
{[14,144]}\end{array}$ & $\begin{array}{l}22.07 \\
{[4,285]}\end{array}$ & $\begin{array}{c}48.15 \\
{[106,848]}\end{array}$ & $\begin{array}{c}42.87 \\
{[96,607]}\end{array}$ \\
\hline Economists & $\begin{array}{l}18.76 \\
{[3,864]}\end{array}$ & $\begin{array}{c}16.84 \\
{[665]}\end{array}$ & $\begin{array}{c}32.44 \\
{[13,451]}\end{array}$ & $\begin{array}{c}76.13 \\
{[228,013]}\end{array}$ \\
\hline Clergy & $\begin{array}{l}20.54 \\
{[5,249]}\end{array}$ & $\begin{array}{l}14.25 \\
{[1,060]}\end{array}$ & $\begin{array}{c}27.79 \\
{[24,984]}\end{array}$ & $\begin{array}{c}24.96 \\
{[33,676]}\end{array}$ \\
\hline Insurance agents & $\begin{array}{l}10.46 \\
{[2,424]}\end{array}$ & $\begin{array}{c}0.00 \\
{[0]}\end{array}$ & $\begin{array}{c}28.69 \\
{[14,625]}\end{array}$ & $\begin{array}{c}32.69 \\
{[32,178]}\end{array}$ \\
\hline Managers and administrators & $\begin{array}{c}16.77 \\
{[92,505]}\end{array}$ & $\begin{array}{c}17.10 \\
{[26,282]}\end{array}$ & $\begin{array}{c}28.59 \\
{[295,689]}\end{array}$ & $\begin{array}{c}36.48 \\
{[1,609,614]}\end{array}$ \\
\hline Carpenters & $\begin{array}{l}1.05 \\
{[2,011]}\end{array}$ & $\begin{array}{l}0.28 \\
{[207]}\end{array}$ & $\begin{array}{c}2.20 \\
{[13,349]}\end{array}$ & $\begin{array}{c}2.04 \\
{[8,108]}\end{array}$ \\
\hline Auto mechanics & $\begin{array}{c}0.29 \\
{[1,110]}\end{array}$ & $\begin{array}{c}1.19 \\
{[1,132]}\end{array}$ & $\begin{array}{c}0.47 \\
{[3,351]}\end{array}$ & $\begin{array}{c}1.36 \\
{[9,286]}\end{array}$ \\
\hline Telephone line installers & $\begin{array}{l}0.76 \\
{[195]}\end{array}$ & $\begin{array}{c}0.00 \\
{[0]}\end{array}$ & $\begin{array}{c}6.28 \\
{[1,620]}\end{array}$ & $\begin{array}{c}3.05 \\
{[3,393]}\end{array}$ \\
\hline Drivers & $\begin{array}{c}0.17 \\
{[2,070]}\end{array}$ & $\begin{array}{l}0.40 \\
{[895]}\end{array}$ & $\begin{array}{c}1.20 \\
{[25,395]}\end{array}$ & $\begin{array}{c}1.59 \\
{[39,580]}\end{array}$ \\
\hline Police and Detectives & $\begin{array}{c}2.28 \\
{[1,746]}\end{array}$ & $\begin{array}{l}11.86 \\
{[1,348]}\end{array}$ & $\begin{array}{c}11.71 \\
{[17,188]}\end{array}$ & $\begin{array}{c}12.23 \\
{[27,822]} \\
\end{array}$ \\
\hline \multicolumn{5}{|c|}{ Traditionally Female Occupations } \\
\hline Occupation & 1978 & 1988 & 1998 & 2007 \\
\hline Registered nurses & $\begin{array}{c}86.94 \\
{[247,258]}\end{array}$ & $\begin{array}{c}89.92 \\
{[40,139]}\end{array}$ & $\begin{array}{c}86.83 \\
{[59,379]}\end{array}$ & $\begin{array}{c}86.48 \\
{[87,428]}\end{array}$ \\
\hline Librarians & $\begin{array}{c}89.56 \\
{[14,847]}\end{array}$ & $\begin{array}{l}82.10 \\
{[3,595]}\end{array}$ & $\begin{array}{c}92.55 \\
{[14,769]}\end{array}$ & $\begin{array}{l}79.41 \\
{[4,259]}\end{array}$ \\
\hline Schoolteachers & $\begin{array}{c}90.58 \\
{[796,709]}\end{array}$ & $\begin{array}{c}88.87 \\
{[88,539]}\end{array}$ & $\begin{array}{c}91.41 \\
{[1,261,264]}\end{array}$ & $\begin{array}{c}81.54 \\
{[1,942,572]}\end{array}$ \\
\hline Bank tellers & $\begin{array}{c}54.70 \\
{[119,922]}\end{array}$ & $\begin{array}{c}72.43 \\
{[38,834]}\end{array}$ & $\begin{array}{c}51.94 \\
{[115,502]}\end{array}$ & $\begin{array}{c}55.51 \\
{[49,831]}\end{array}$ \\
\hline Secretaries & $\begin{array}{c}52.23 \\
{[944,816]}\end{array}$ & $\begin{array}{c}98.26 \\
{[36,688]}\end{array}$ & $\begin{array}{c}61.48 \\
{[194,194]}\end{array}$ & $\begin{array}{c}62.39 \\
{[1,362,068]}\end{array}$ \\
\hline Typists & $\begin{array}{c}37.04 \\
{[56,654]}\end{array}$ & $\begin{array}{l}26.25 \\
{[2,699]}\end{array}$ & $\begin{array}{c}91.82 \\
{[372,472]}\end{array}$ & $\begin{array}{l}13.40 \\
{[6,007]}\end{array}$ \\
\hline Sewing machine operators & $\begin{array}{c}95.17 \\
{[844,866]}\end{array}$ & $\begin{array}{c}97.00 \\
{[144,360]}\end{array}$ & $\begin{array}{c}93.54 \\
{[1,200,793]}\end{array}$ & $\begin{array}{c}91.99 \\
{[1,213,158]}\end{array}$ \\
\hline Dental assistants & $\begin{array}{c}22.53 \\
{[10,467]}\end{array}$ & $\begin{array}{l}22.87 \\
{[2,303]}\end{array}$ & $\begin{array}{c}53.49 \\
{[56,295]}\end{array}$ & $\begin{array}{c}55.27 \\
{[90,547]}\end{array}$ \\
\hline Child care workers & - & $\begin{array}{c}100.00 \\
{[6,739]}\end{array}$ & $\begin{array}{c}97.86 \\
{[407,142]}\end{array}$ & $\begin{array}{c}97.76 \\
{[305,128]}\end{array}$ \\
\hline
\end{tabular}

Source: PNADs and author's tabulation.

All estimations are weighted by the individual weight available in the database.

(Between squared brackets is the number of observations in the sample, using the appropriate weight. 
with women in a "female job." In that case, the premium could be so high that firm owners prefer to hire only women because they are less costly. Another alternative is that society resists having men in these occupations. For example, male nurses may be less socially desirable than female nurses. A man who chooses to become a nurse may be viewed as a "failed doctor" more easily than a woman. ${ }^{9}$ This explanation is commonly known as "consumer prejudice" (Patterson \& Engelberg 1978).

These differences in occupations and industry choices may be determinants of the remuneration discrepancy between genders. In order to better control this effect, Table 2 provides the individuals' hourly pay by occupation and gender ${ }^{10}$ for 1978 and 2007. Table 3 does the same for economic sector and gender.

Using the same categories analyzed in Table 1, it can be seen that, in most cases, men have higher salaries than women. In 1978, for only two occupations, drivers and librarians, did females have a higher average salary than males. For another 16 occupations, men received higher remuneration than women. In 2007, the situation is slightly different: in 12 occupations, men earn greater wages than women and, for three others, women earn higher wages than men (auto mechanics, drivers, and police and detectives). With no controls for education and industry, which we examine in the next section, it appears that there has been little change in the gender wage gap over a long period of time.

Concerning industry sectors, Table 3 shows that men typically received higher wages than women in the past. However, in one activity, women's salaries are higher: construction. This is also one of the activities with lower female engagement. One possible explanation for this premium on female wages is individual selection. In order to participate in this industry, women have to be so different from the average that they receive higher wages than men. Analyzing the education distribution among industries, it can be seen that in the construction industry women are more educated than men. In 1978 , almost 60 percent of females in the construction industry had 9 or more years of education (completed the primary level of education), while less than 8 percent of males in this industry had this level of education. In 2007, 68 percent of women in this industry had more than 9 years of education, while 21 percent of men were in the same condition.

This question raises the importance of analyzing the degree of education. Comparing 1978 and 2007 data, we can see some different trends by gender in Table 4. In 1978, men with a low level of education were concentrated in the agribusiness sector. Women with no education were also in agribusiness, but those who had a small amount of education ( 1 to 4 years) were in services. Men who had 5 to 11 years of education were in the transformation industry, while women at this level were generally in the services and the social sector. Individuals of both genders with more than 11 years of education are more concentrated in the social sector. The picture in 2007 is a little different. Men with low education levels continue to work in agribusiness (until 4 years of education), and women in services. However, after finishing the basic

\footnotetext{
${ }^{9}$ Anecdotal evidence of this can be seen in the Hollywood hit movie "Meet the Parents," where the parents of the fiancée avoid saying that their future son-in-law is a nurse.

${ }^{10}$ Here we do not control for hours of work or qualification (education degree, for example). These additional controls and others will be the focus of the next sections, with the regression model.
} 
Table 2: Hourly wage by gender and occupation: 1978 and 2007.

\begin{tabular}{|c|c|c|c|c|}
\hline \multirow[b]{2}{*}{ Occupation } & \multicolumn{2}{|c|}{1978} & \multicolumn{2}{|c|}{2007} \\
\hline & Men & Women & Men & Women \\
\hline Engineers & $\begin{array}{c}178.55 \\
{[513]}\end{array}$ & $\begin{array}{c}158.88^{*} \\
{[23]}\end{array}$ & $\begin{array}{c}31.00 \\
{[476]}\end{array}$ & $\begin{array}{c}22.45 \\
{[64]}\end{array}$ \\
\hline Lawyers & $\begin{array}{c}206.96 \\
{[397]}\end{array}$ & $\begin{array}{c}135.82^{*} \\
{[103]}\end{array}$ & $\begin{array}{l}22.84 \\
{[515]}\end{array}$ & $\begin{array}{l}19.32^{*} \\
{[384]}\end{array}$ \\
\hline Physicians & $\begin{array}{c}263.65 \\
{[383]}\end{array}$ & $\begin{array}{c}125.52^{*} \\
{[96]}\end{array}$ & $\begin{array}{l}51.23 \\
{[260]}\end{array}$ & $\begin{array}{l}35.15^{*} \\
{[196]}\end{array}$ \\
\hline Economists & $\begin{array}{c}246.08 \\
{[117]}\end{array}$ & $\begin{array}{c}130.70^{*} \\
{[38]}\end{array}$ & $\begin{array}{l}23.29 \\
{[136]}\end{array}$ & $\begin{array}{c}14.74^{*} \\
{[467]}\end{array}$ \\
\hline Clergy & $\begin{array}{l}34.85 \\
{[100]}\end{array}$ & $\begin{array}{c}14.40^{*} \\
{[24]}\end{array}$ & $\begin{array}{l}7.22 \\
{[217]}\end{array}$ & $\begin{array}{l}3.99^{*} \\
{[75]}\end{array}$ \\
\hline Insurance agents & $\begin{array}{l}69.06 \\
{[122]}\end{array}$ & $\begin{array}{c}80.63 \\
{[13]}\end{array}$ & $\begin{array}{l}13.51 \\
{[110]}\end{array}$ & $\begin{array}{c}11.89 \\
{[49]}\end{array}$ \\
\hline Managers and administrators & $\begin{array}{c}99.08 \\
{[2,546]}\end{array}$ & $\begin{array}{l}70.11^{*} \\
{[618]}\end{array}$ & $\begin{array}{l}17.97 \\
{[5534]}\end{array}$ & $\begin{array}{l}15.34^{*} \\
{[3294]}\end{array}$ \\
\hline Carpenters & $\begin{array}{l}21.69 \\
{[931]}\end{array}$ & $8.56^{*}$ & $\begin{array}{c}4.36 \\
{[814]}\end{array}$ & $\begin{array}{l}2.26^{*} \\
{[15]}\end{array}$ \\
\hline Auto mechanics & $\begin{array}{c}24.04 \\
{[1,768]}\end{array}$ & $\begin{array}{c}10.70^{*} \\
{[4]}\end{array}$ & $\begin{array}{r}4.95 \\
{[1382]}\end{array}$ & $\begin{array}{l}8.30^{*} \\
{[21]}\end{array}$ \\
\hline Telephone line installers & $\begin{array}{l}34.54 \\
{[140]}\end{array}$ & $\begin{array}{c}19.79^{*} \\
{[1]}\end{array}$ & $\begin{array}{l}5.36 \\
{[200]}\end{array}$ & $\begin{array}{l}4.64^{*} \\
{[4]}\end{array}$ \\
\hline Drivers & $\begin{array}{c}27.13 \\
{[5,549]}\end{array}$ & $\begin{array}{c}38.04^{*} \\
{[11]}\end{array}$ & $\begin{array}{c}6.36 \\
{[4831]}\end{array}$ & $\begin{array}{l}8.42^{*} \\
{[75]}\end{array}$ \\
\hline Police and Detectives & $\begin{array}{l}52.64 \\
{[440]}\end{array}$ & $\begin{array}{c}43.43^{*} \\
{[12]}\end{array}$ & $\begin{array}{l}12.47 \\
{[448]}\end{array}$ & $15.44^{*}$ \\
\hline Registered nurses & $\begin{array}{l}31.38 \\
{[190]}\end{array}$ & $\begin{array}{l}22.76 \\
{[1322]}\end{array}$ & $\begin{array}{c}12.40 \\
{[24]}\end{array}$ & $\begin{array}{l}12.76 \\
{[177]}\end{array}$ \\
\hline Librarians & 26.60 & $\begin{array}{c}51.22^{*} \\
{[97]}\end{array}$ & 91.61 & $\begin{array}{c}11.86 \\
{[10]}\end{array}$ \\
\hline Schoolteachers & $\begin{array}{l}55.65 \\
{[429]}\end{array}$ & $\begin{array}{l}33.31^{*} \\
{[4174]}\end{array}$ & $\begin{array}{c}9.87 \\
{[932]}\end{array}$ & $\begin{array}{c}8.75^{*} \\
{[3882]}\end{array}$ \\
\hline Bank tellers & $\begin{array}{l}51.43 \\
{[531]}\end{array}$ & $\begin{array}{l}22.36^{*} \\
{[635]}\end{array}$ & $\begin{array}{c}12.48 \\
{[70]}\end{array}$ & $\begin{array}{l}9.02^{*} \\
{[72]}\end{array}$ \\
\hline Secretaries & $\begin{array}{c}32.70 \\
{[4,694]}\end{array}$ & $\begin{array}{l}29.56^{*} \\
{[5251]}\end{array}$ & $\begin{array}{r}7.43 \\
{[1715]}\end{array}$ & $\begin{array}{c}5.93^{*} \\
{[2764]}\end{array}$ \\
\hline Typists & $\begin{array}{l}28.00 \\
{[553]}\end{array}$ & $\begin{array}{l}22.12^{*} \\
{[394]}\end{array}$ & $\begin{array}{l}8.01 \\
{[70]}\end{array}$ & $\begin{array}{l}2.81^{*} \\
{[11]}\end{array}$ \\
\hline Sewing machine operators & $\begin{array}{l}30.26 \\
{[213]}\end{array}$ & $\begin{array}{l}12.57^{*} \\
{[4090]}\end{array}$ & $\begin{array}{c}3.29 \\
{[212]}\end{array}$ & $\begin{array}{c}3.25 \\
{[2495]}\end{array}$ \\
\hline Dental assistants & $\begin{array}{c}192.14 \\
{[214]}\end{array}$ & $\begin{array}{c}133.04^{*} \\
{[69]}\end{array}$ & $\begin{array}{l}23.58 \\
{[138]}\end{array}$ & $\begin{array}{l}21.64 \\
{[169]}\end{array}$ \\
\hline Child care workers & & & $\begin{array}{l}6.79 \\
{[18]}\end{array}$ & $\begin{array}{c}7.00 \\
{[564]}\end{array}$ \\
\hline
\end{tabular}

Source: PNADs and author's tabulation.

All estimations are weighted by the individual weight available in the database.

* Indicates that the female and male values are different at $95 \%$ confidence interval Between square brackets is the number of observations in the sample, using the appropriate weight 
Table 3: Hourly wage by gender and industries: 1978 and 2007.

\begin{tabular}{|c|c|c|c|c|}
\hline \multirow[b]{2}{*}{ Activity } & \multicolumn{2}{|c|}{1978} & \multicolumn{2}{|c|}{2007} \\
\hline & Men & Women & Men & Women \\
\hline Agricultural & 14.86 & $6.49^{*}$ & 3.10 & $0.91^{*}$ \\
\hline Transformation Industry & 38.11 & $17.42^{*}$ & 7.12 & $4.33^{*}$ \\
\hline Construction & 23.21 & $38.82^{*}$ & 4.72 & $19.72^{*}$ \\
\hline General Industry & 31.46 & 33.10 & 10.45 & 11.02 \\
\hline Commerce & 38.26 & $21.81^{*}$ & 6.48 & $4.83^{*}$ \\
\hline Services & 40.00 & $12.30^{*}$ & 7.65 & $3.56^{*}$ \\
\hline Transportation & 32.67 & $26.39^{*}$ & 7.28 & 7.45 \\
\hline Social Services & 74.35 & $32.77^{*}$ & 13.45 & $8.26^{*}$ \\
\hline Public Administration & 50.08 & $45.15^{*}$ & 12.02 & $10.99^{*}$ \\
\hline Other Activities & 78.14 & $38.85^{*}$ & 9.12 & $7.04^{*}$ \\
\hline
\end{tabular}

level of education, i.e., 4 years, men are employed in commerce. Women, for their part, continue to be concentrated in services until completing the fundamental level of education, i.e., 8 years, and after that, they compose a larger fraction of commerce.

\section{Econometric model to calculate discrimination between genders}

The previous analysis illustrates that male and female workers have different allocations within and returns to the labor market in Brazil. We now present an econometric analysis in order to control for distinct influences on individual remuneration. Using this procedure, we will also be able to measure the impact of occupational choices and individual characteristics on the hourly wage.

The basic model follows Mincer (1995). The mincerian equation relates the hourly wage with individual demographics and job definitions, as shown by equation (1).

$$
\ln w_{i}=\alpha+\sum_{j=1}^{k} \beta_{j} X_{i}+\sum_{s=1}^{m} \gamma_{s} Z_{i}+\varepsilon_{i},
$$

where $w_{i}$ is the hourly wage for individual $i$ and $X_{i}$ are the demographics for individual $i . Z_{i}$ represents dummy variables for activities and occupations for each individual ${ }^{11}$.

By demographics, we mean individual age and its squared value (to account for the concavity on remuneration), residence region ${ }^{12}$ and education dummies. ${ }^{13} Z_{i}$ is composed of both occupation and industry dummies. For

\footnotetext{
${ }^{11}$ Excluded category is Agricultural Business.

${ }^{12}$ Excluded category is Southeast, the richest Brazilian region.

${ }^{13}$ Excluded category 'no education'. Other categories are: basic (1 to 4 years), fundamental (5 to 8 years), high school ( 9 to 11 years) and college or more (12 or more years).
} 
Table 4: Percentage male and female by education and industry: 1978 and 2007.

\begin{tabular}{|c|c|c|c|c|c|}
\hline & \multicolumn{5}{|l|}{1978} \\
\hline & \multicolumn{5}{|c|}{ years of education } \\
\hline & 0 & 1 to 4 & 5 to 8 & 9 to 11 & $12+$ \\
\hline \multicolumn{6}{|c|}{ Male Workers } \\
\hline Agribusiness & 62.82 & 30.92 & 9.28 & 3.39 & 1.39 \\
\hline Transformation & 8.67 & 19.73 & 24.87 & 24.65 & 19.92 \\
\hline Construction & 11.40 & 14.71 & 9.71 & 4.78 & 5.54 \\
\hline Other industrial activities & 1.86 & 2.38 & 2.13 & 3.22 & 3.13 \\
\hline Commerce & 5.45 & 9.75 & 15.55 & 17.10 & 7.66 \\
\hline Services & 4.68 & 9.82 & 14.59 & 13.57 & 15.05 \\
\hline Transportation and Communication & 2.68 & 6.87 & 9.47 & 6.17 & 3.34 \\
\hline Social & 0.74 & 1.77 & 3.50 & 5.63 & 21.03 \\
\hline Public Administration & 1.10 & 2.99 & 7.87 & 10.39 & 13.23 \\
\hline Other activities & 0.59 & 1.07 & 3.03 & 11.11 & 9.71 \\
\hline \multicolumn{6}{|c|}{ Female Workers } \\
\hline Agribusiness & 49.00 & 23.37 & 5.55 & 0.37 & 0.06 \\
\hline Transformation & 6.71 & 14.00 & 17.68 & 11.16 & 6.89 \\
\hline Construction & 0.10 & 0.24 & 0.47 & 1.29 & 1.55 \\
\hline Other industrial activities & 0.32 & 0.28 & 0.31 & 1.05 & 1.56 \\
\hline Commerce & 3.72 & 7.82 & 17.25 & 12.85 & 4.08 \\
\hline Services & 35.87 & 42.26 & 31.07 & 12.27 & 7.70 \\
\hline Transportation and Communication & 0.20 & 0.72 & 1.90 & 2.78 & 2.03 \\
\hline Social & 2.65 & 8.95 & 20.00 & 43.35 & 57.74 \\
\hline Public Administration & 0.39 & 1.06 & 3.33 & 7.35 & 10.46 \\
\hline Other activities & 1.04 & 1.29 & 2.43 & 7.55 & 7.94 \\
\hline \multicolumn{6}{|c|}{2007} \\
\hline & \multicolumn{5}{|c|}{ years of education } \\
\hline & 0 & 1 to 4 & 5 to 8 & 9 to 11 & $12+$ \\
\hline \multicolumn{6}{|c|}{ Male Workers } \\
\hline Agribusiness & 53.37 & 35.28 & 15.30 & 5.78 & 1.82 \\
\hline Transformation & 7.95 & 12.11 & 18.36 & 21.93 & 13.70 \\
\hline Construction & 14.54 & 18.55 & 16.50 & 7.07 & 3.43 \\
\hline Other industrial activities & 0.84 & 0.93 & 1.13 & 1.83 & 1.66 \\
\hline Commerce & 9.84 & 13.20 & 21.04 & 24.69 & 16.05 \\
\hline Services & 2.86 & 3.27 & 3.72 & 3.95 & 4.86 \\
\hline Transportation and Communication & 3.75 & 6.87 & 9.91 & 9.07 & 5.20 \\
\hline Social & 0.67 & 1.01 & 1.40 & 3.53 & 16.42 \\
\hline Public Administration & 2.03 & 2.67 & 3.12 & 7.89 & 13.38 \\
\hline Other activities & 4.15 & 6.09 & 9.51 & 14.25 & 23.47 \\
\hline \multicolumn{6}{|c|}{ Female Workers } \\
\hline Agribusiness & 44.39 & 31.19 & 11.32 & 2.93 & 0.59 \\
\hline Transformation & 8.12 & 11.74 & 16.08 & 14.21 & 6.87 \\
\hline Construction & 0.29 & 0.36 & 0.35 & 0.55 & 0.95 \\
\hline Other industrial activities & 0.11 & 0.07 & 0.11 & 0.26 & 0.68 \\
\hline Commerce & 8.32 & 9.43 & 15.36 & 25.48 & 11.86 \\
\hline Services & 27.98 & 33.26 & 36.66 & 18.25 & 4.78 \\
\hline Transportation and Communication & 0.31 & 0.42 & 0.85 & 2.43 & 2.55 \\
\hline Social & 3.51 & 5.16 & 6.59 & 17.70 & 44.52 \\
\hline Public Administration & 1.25 & 1.46 & 2.10 & 5.21 & 10.67 \\
\hline Other activities & 5.71 & 6.90 & 10.57 & 12.98 & 16.53 \\
\hline
\end{tabular}

Source: PNADs and author's tabulation.

All estimations are weighted by the individual weight available in the database. 
all years, we used the classification of these variables on two and three-digit dummies. Here, it is necessary to point out the endogeneity of these latter variables, especially occupation. It is well known that occupational choices are made according to individual preferences, and that such choices imply different levels of remuneration, linking the dependent variable with this individual choice. An instrumental variable could be used to correct for this problem. Unfortunately, the database used in this study does not allow for the construction of such a variable. Therefore, we continue to control for occupation and industry choice while ignoring this possible effect, but using the same methodology used in the literature.

We were also able to test for the influence of occupational distinction of authority on wages. Budig \& England (2001) created a dummy variable for authority in their study on the wage penalty of motherhood. This variable was constructed by coding all occupations that have the words "management," "supervisor" or "foreman" in their description as one. As a dependent variable, they used the natural log of hourly wage in the respondent's current job. They find that mothers are less likely to be in jobs involving authority; however, this does not seem to affect the estimated motherhood penalty. In our work, "authority" was included as a variable of job characteristics. This variable is a dummy, coded one for occupational categories with titles containing the words "supervisor," "manager" or "director." We used this additional variable only for the 2007 data, which is more complete. Also, for 2007, we included race dummies ${ }^{14}$ and tenure on the job ${ }^{15}$ in order to have a more complete set of controls. ${ }^{16}$

Since the main purpose of this study is to analyze female labor characteristics, we estimated equation (1) separately for men and women using ordinary least squares. We did not use a Heckman correction for the female equation because we are concerned only with working individuals. ${ }^{17}$ These regressions result in two different outcomes, posed as equations (2) and (3).

$$
\begin{gathered}
\ln w_{i}^{F}=\hat{\alpha}^{F}+\sum_{j=1}^{k} \hat{\beta}_{j}^{F} X_{i}^{F}+\sum_{s=1}^{m} \hat{\gamma}_{s}^{F} Z_{i}^{F}+\varepsilon_{i} \\
\ln w_{i}^{M}=\hat{\alpha}^{M}+\sum_{j=1}^{k} \hat{\beta}_{j}^{M} X_{i}^{M}+\sum_{s=1}^{m} \hat{\gamma}_{s}^{M} Z_{i}^{M}+\varepsilon_{i},
\end{gathered}
$$

where equation (2) uses only female data to estimate the coefficients, and equation (3) uses the male data to this end. These features allow us use the Oaxaca (1973) method to estimate the male-female differences not explained by individual characteristics.

\footnotetext{
${ }^{14}$ Excluded category is White; other categories are Black, Mulato, Asian and Native.

${ }^{15}$ Excluded category is "less than 6 months"; other categories are " 6 months to 1 year," " 1 to 2 years," " 2 to 5 years" and "more then 5 years."

${ }^{16}$ Since 1976, IBGE changed the PNAD questionnaires many times. We do not have all of the basic variables for all years. Therefore, we estimated a more complete equation only for 2007, but kept the "basic" regression for all years for comparison.

${ }^{17}$ The current literature on gender wage gap usually avoids using a Heckman selection because it is less compatible with Oaxaca methodology. However, when it is used, results do not change significantly, as demonstrated by Galarza et al. (2006). As a test, we performed the estimation using a Heckman correction to our data, and also got results compatible with those presented in this paper.
} 
The male-female wage differential can be posed in two parts: the explained portion of the differential (explained by the different characteristics of men and women) and the unexplained differential.

Using the estimated coefficients for female and male individuals, we calculate the hourly wage one individual would receive if he or she were male and, the alternative possibility, if he or she were female. We use these computations to determine the wage differential that is not explained by observable characteristics, as shown in equation (4):

$$
\hat{D}_{i}=\sum_{j} \hat{\beta}_{j}^{M} X_{i}-\sum_{j} \hat{\beta}_{j}^{F} X_{i} .
$$

We compare the estimated value of equation (4) for each individual and use the population average for this variable as the estimation of the nonexplained portion of the gender wage gap across the years. The greater the value of the difference in the sample, the greater the gender discrimination in the sample. ${ }^{18}$ In the next section, we present the results.

\section{And the difference between genders is...}

We estimate equations (2) and (3) separately for the different samples (1978, 1988, 1998 and 2007). As mentioned earlier, for 2007, because of the availability of additional variables, we included extra controls for race, tenure and authority. Our baseline regression includes demographics, industry sector and two-digit occupational controls. The final model also includes occupational codes with three digits. ${ }^{19}$ All of our estimations were calculated using the individual weight available in the PNAD, as well as robust standard errors to correct for heteroscedasticity.

Tables 5 through 8 show the estimated results, disaggregated by gender. Columns (1) and (3) refer to the male results, and columns (2) and (4) refer to female results. For all years, we find a positive effect of age, with concavity expressed by the variable age squared. These effects are expected, because they reflect the worker's experience with the labor market. The concavity is verified because the incremental value of experience along the years has decreasing returns to productivity and, consequently, to individual remuneration. Some studies use the age variable as a proxy for experience. However, this is not a good approach to infer women's labor experience, because they experience time out of the labor market to have and raise children. Therefore, the variable "age" measures the impact of age itself, more so than labor experience. In order to have some control for labor experience, the regression

\footnotetext{
${ }^{18}$ The D statistic can either be an overestimation or underestimation of discrimination. Not all of the differences verified on variable $\mathrm{D}$ can be considered discrimination per se. As the available microdata are not complete for the individual characteristics, we only can affirm that we control for the "observable" characteristics of each individual, and the D statistic represents the effect of "non-observable" characteristics available to neither the researcher nor the labor contractors. Therefore, any remaining differences would be the result of some sort of gender discrimination. On the other hand, D may underestimate the discrimination because we control for characteristics like occupation, and, if there is non-market discrimination that induces women to opt for easier and worse remunerated occupations, we would not see it on the final estimation. See Oaxaca (1973).

${ }^{19}$ We have a different number of categories for each year, being more specific in recent years. However, for all samples we used the most detailed variable available.
} 
Table 5: Estimation Results, 1978.

\begin{tabular}{|c|c|c|c|c|}
\hline & $\begin{array}{l}\text { Men } \\
(1)\end{array}$ & $\begin{array}{l}\text { Women } \\
\text { (2) }\end{array}$ & $\begin{array}{l}\text { Men } \\
(3)\end{array}$ & $\begin{array}{c}\text { Women } \\
\text { (4) }\end{array}$ \\
\hline Intercept & $\begin{array}{c}0.36 \\
(13.06)\end{array}$ & $\begin{array}{c}0.17 \\
(3.52)\end{array}$ & $\begin{array}{c}2.11 \\
(19.38)\end{array}$ & $\begin{array}{l}1.47 \\
(4.92)\end{array}$ \\
\hline Age & $\begin{array}{c}0.08 \\
(52.40)\end{array}$ & $\begin{array}{c}0.08 \\
(29.51)\end{array}$ & $\begin{array}{c}0.06 \\
(41.95)\end{array}$ & $\begin{array}{c}0.07 \\
(26.72)\end{array}$ \\
\hline Age Squared & $\begin{array}{l}-0.00 \\
(-40.56)\end{array}$ & $\begin{array}{l}-0.00 \\
(-22.36)\end{array}$ & $\begin{array}{c}-0.00 \\
(-31.92)\end{array}$ & $\begin{array}{c}-0.00 \\
(-20.44)\end{array}$ \\
\hline South & $\begin{array}{l}-0.17 \\
(-21.98)\end{array}$ & $\begin{array}{l}-0.25 \\
(-20.87)\end{array}$ & $\begin{array}{l}-0.18 \\
(-24.80)\end{array}$ & $\begin{array}{l}-0.24 \\
(-20.06)\end{array}$ \\
\hline North & $\begin{array}{l}-0.24 \\
(-18.88)\end{array}$ & $\begin{array}{l}-0.34 \\
(-19.80)\end{array}$ & $\begin{array}{l}-0.23 \\
(-19.30)\end{array}$ & $\begin{array}{l}-0.34 \\
(-20.16)\end{array}$ \\
\hline Northeast & $\begin{array}{l}-0.38 \\
(-60.52)\end{array}$ & $\begin{array}{l}-0.69 \\
(-65.20)\end{array}$ & $\begin{array}{l}-0.40 \\
(-63.88)\end{array}$ & $\begin{array}{l}-0.65 \\
(-62.71)\end{array}$ \\
\hline Center & $\begin{array}{l}-0.09 \\
(-9.08)\end{array}$ & $\begin{array}{l}-0.21 \\
(-14.38)\end{array}$ & $\begin{array}{l}-0.10 \\
(-9.93)\end{array}$ & $\begin{array}{l}-0.20 \\
(-14.56)\end{array}$ \\
\hline Education 1 & $\begin{array}{c}0.33 \\
(48.51)\end{array}$ & $\begin{array}{c}0.30 \\
(22.31)\end{array}$ & $\begin{array}{c}0.25 \\
(37.95)\end{array}$ & $\begin{array}{c}0.21 \\
(16.65)\end{array}$ \\
\hline Education 2 & $\begin{array}{c}0.63 \\
(68.50)\end{array}$ & $\begin{array}{c}0.59 \\
(35.09)\end{array}$ & $\begin{array}{c}0.49 \\
(53.90)\end{array}$ & $\begin{array}{c}0.45 \\
(27.80)\end{array}$ \\
\hline Education 3 & $\begin{array}{l}1.00 \\
(78.26)\end{array}$ & $\begin{array}{c}0.92 \\
(47.76)\end{array}$ & $\begin{array}{c}0.83 \\
(66.77)\end{array}$ & $\begin{array}{c}0.79 \\
(41.07)\end{array}$ \\
\hline Education 4 & $\begin{array}{c}1.69 \\
(104.70)\end{array}$ & $\begin{array}{c}1.55 \\
(70.46)\end{array}$ & $\begin{array}{l}1.30 \\
(75.93)\end{array}$ & $\begin{array}{l}1.24 \\
(54.42)\end{array}$ \\
\hline Transformation Industry & $\begin{array}{c}0.09 \\
(4.69)\end{array}$ & $\begin{array}{c}-0.09 \\
(-0.75)\end{array}$ & $\begin{array}{c}0.29 \\
(10.46)\end{array}$ & $\begin{array}{l}0.56 \\
(4.54)\end{array}$ \\
\hline Construction & $\begin{array}{l}-0.03 \\
(-1.42)\end{array}$ & $\begin{array}{c}0.12 \\
(0.98)\end{array}$ & $\begin{array}{l}0.27 \\
(9.30)\end{array}$ & $\begin{array}{l}0.67 \\
(5.24)\end{array}$ \\
\hline General Industry & $\begin{array}{l}0.02 \\
(0.74)\end{array}$ & $\begin{array}{l}0.01 \\
(0.01)\end{array}$ & $\begin{array}{c}0.28 \\
(8.85)\end{array}$ & $\begin{array}{c}0.70 \\
(5.37)\end{array}$ \\
\hline Commerce & $\begin{array}{l}-0.07 \\
(-3.19)\end{array}$ & $\begin{array}{c}-0.15 \\
(-1.29)\end{array}$ & $\begin{array}{c}0.24 \\
(8.08)\end{array}$ & $\begin{array}{l}0.43 \\
(3.48)\end{array}$ \\
\hline Services & $\begin{array}{l}-0.01 \\
(-0.75)\end{array}$ & $\begin{array}{c}-0.17 \\
(-1.50)\end{array}$ & $\begin{array}{l}0.19 \\
(6.36)\end{array}$ & $\begin{array}{l}0.41 \\
(3.28)\end{array}$ \\
\hline Transportation & $\begin{array}{c}0.22 \\
(9.86)\end{array}$ & $\begin{array}{l}0.01 \\
(0.01)\end{array}$ & $\begin{array}{c}0.37 \\
(12.69)\end{array}$ & $\begin{array}{l}0.57 \\
(4.51)\end{array}$ \\
\hline Social Services & $\begin{array}{c}-0.12 \\
(-4.87)\end{array}$ & $\begin{array}{c}-0.21 \\
(-1.80)\end{array}$ & $\begin{array}{c}0.22 \\
(6.95)\end{array}$ & $\begin{array}{c}0.48 \\
(3.93)\end{array}$ \\
\hline Public Administration & $\begin{array}{c}0.13 \\
(5.71)\end{array}$ & $\begin{array}{c}0.08 \\
(0.71)\end{array}$ & $\begin{array}{c}0.28 \\
(8.88)\end{array}$ & $\begin{array}{l}0.70 \\
(5.64)\end{array}$ \\
\hline Other Activities & $\begin{array}{l}0.21 \\
(8.14)\end{array}$ & $\begin{array}{l}0.25 \\
(2.20)\end{array}$ & $\begin{array}{c}0.54 \\
(15.93)\end{array}$ & $\begin{array}{l}0.90 \\
(7.20)\end{array}$ \\
\hline Occupations 2 digits & Yes & Yes & No & No \\
\hline Occupations 3 digits & No & No & Yes & Yes \\
\hline Adjusted $R^{2}$ & 0.5267 & 0.5497 & 0.5829 & 0.5979 \\
\hline Number of Observations & 103142 & 44493 & 103142 & 44493 \\
\hline
\end{tabular}

for 2007 also includes the variable "tenure on the job," which captures part of this effect.

The second variable category is the regional dummies. Except for 2007, Southeast, the excluded category, has the greatest positive impact on wages for both men and women. In 2007, it is possible to verify that Center is the region with higher wages for both men and women in all regressions. This may be an effect of migration to the Southeast, which began in the 1960s and stabilized at the end of the 1990s as growth registered in the Central region, which was poorly occupied until the end of the 1980 s. $^{20}$

\footnotetext{
${ }^{20}$ During the 1950s, the capital city of Brazil moved from Rio de Janeiro (Southeast) to Brasilia (Center). However, the population boom in the region continued until the 1980s, not only in the new capital but also in other states such as Mato Grosso and Mato Grosso do Sul, where
} 
Table 6: Estimation Results, 1988.

\begin{tabular}{|c|c|c|c|c|}
\hline & $\begin{array}{c}\text { Men } \\
(1)\end{array}$ & $\begin{array}{l}\text { Women } \\
\text { (2) }\end{array}$ & $\begin{array}{c}\text { Men } \\
(3)\end{array}$ & $\begin{array}{c}\text { Women } \\
\text { (4) }\end{array}$ \\
\hline Intercept & $\begin{array}{c}2.89 \\
(15.15)\end{array}$ & $\begin{array}{c}3.18 \\
(14.35)\end{array}$ & $\begin{array}{c}4.75 \\
(16.12)\end{array}$ & $\begin{array}{c}4.69 \\
(14.60)\end{array}$ \\
\hline Age & $\begin{array}{c}0.08 \\
(8.31)\end{array}$ & $\begin{array}{c}0.06 \\
(4.90)\end{array}$ & $\begin{array}{c}0.06 \\
(6.06)\end{array}$ & $\begin{array}{c}0.04 \\
(3.04)\end{array}$ \\
\hline Age Squared & $\begin{array}{l}-0.00 \\
(-6.36)\end{array}$ & $\begin{array}{l}-0.00 \\
(-3.45)\end{array}$ & $\begin{array}{l}-0.00 \\
(-4.61)\end{array}$ & $\begin{array}{l}-0.00 \\
(-2.16)\end{array}$ \\
\hline South & $\begin{array}{c}-0.21 \\
(-4.62)\end{array}$ & $\begin{array}{c}-0.15 \\
(-2.38)\end{array}$ & $\begin{array}{c}-0.22 \\
(-4.55)\end{array}$ & $\begin{array}{c}-0.15 \\
(-2.30)\end{array}$ \\
\hline North & $\begin{array}{l}-0.01 \\
(-0.02)\end{array}$ & $\begin{array}{l}-0.12 \\
(-1.66)\end{array}$ & $\begin{array}{l}0.01 \\
(0.14)\end{array}$ & $\begin{array}{l}-0.16 \\
(-2.08)\end{array}$ \\
\hline Northeast & $\begin{array}{l}-0.49 \\
(-9.91)\end{array}$ & $\begin{array}{c}-0.66 \\
(-9.19)\end{array}$ & $\begin{array}{c}-0.49 \\
(-9.73)\end{array}$ & $\begin{array}{c}-0.68 \\
(-8.54)\end{array}$ \\
\hline Center & $\begin{array}{l}-0.14 \\
(-3.12)\end{array}$ & $\begin{array}{c}-0.09 \\
(-1.70)\end{array}$ & $\begin{array}{l}-0.10 \\
(-2.27)\end{array}$ & $\begin{array}{c}-0.11 \\
(-1.91)\end{array}$ \\
\hline Education 1 & $\begin{array}{c}0.38 \\
(8.43)\end{array}$ & $\begin{array}{c}0.39 \\
(5.55)\end{array}$ & $\begin{array}{l}0.28 \\
(6.07)\end{array}$ & $\begin{array}{l}0.28 \\
(3.95)\end{array}$ \\
\hline Education 2 & $\begin{array}{c}0.68 \\
(12.53)\end{array}$ & $\begin{array}{c}0.63 \\
(6.18)\end{array}$ & $\begin{array}{l}0.50 \\
(9.00)\end{array}$ & $\begin{array}{l}0.46 \\
(4.29)\end{array}$ \\
\hline Education 3 & $\begin{array}{c}1.09 \\
(14.08)\end{array}$ & $\begin{array}{l}1.10 \\
(9.09)\end{array}$ & $\begin{array}{c}0.86 \\
(11.09)\end{array}$ & $\begin{array}{l}0.93 \\
(7.29)\end{array}$ \\
\hline Education 4 & $\begin{array}{c}1.73 \\
(20.60)\end{array}$ & $\begin{array}{l}1.80 \\
(11.17)\end{array}$ & $\begin{array}{c}1.34 \\
(13.18)\end{array}$ & $\begin{array}{l}1.46 \\
(7.40)\end{array}$ \\
\hline Transformation Industry & $\begin{array}{c}0.20 \\
(2.24)\end{array}$ & $\begin{array}{c}-0.69 \\
(-0.97)\end{array}$ & $\begin{array}{c}0.38 \\
(3.43)\end{array}$ & $\begin{array}{c}0.29 \\
(1.15)\end{array}$ \\
\hline Construction & $\begin{array}{l}-0.07 \\
(-0.81)\end{array}$ & $\begin{array}{c}-0.61 \\
(-0.84)\end{array}$ & $\begin{array}{l}0.28 \\
(2.46)\end{array}$ & $\begin{array}{l}0.76 \\
(2.28)\end{array}$ \\
\hline General Industry & $\begin{array}{c}0.33 \\
(2.86)\end{array}$ & $\begin{array}{c}-0.02 \\
(-0.03)\end{array}$ & $\begin{array}{c}0.56 \\
(3.63)\end{array}$ & $\begin{array}{l}0.85 \\
(2.77)\end{array}$ \\
\hline Commerce & $\begin{array}{l}-0.01 \\
(-0.13)\end{array}$ & $\begin{array}{c}-0.68 \\
(-0.99)\end{array}$ & $\begin{array}{l}0.28 \\
(2.28)\end{array}$ & $\begin{array}{l}0.35 \\
(1.39)\end{array}$ \\
\hline Services & $\begin{array}{l}-0.10 \\
(-0.88)\end{array}$ & $\begin{array}{c}-0.85 \\
(-1.24)\end{array}$ & $\begin{array}{l}-0.02 \\
(-0.14)\end{array}$ & $\begin{array}{l}0.13 \\
(0.53)\end{array}$ \\
\hline Transportation & $\begin{array}{l}0.28 \\
(2.77)\end{array}$ & $\begin{array}{c}-0.31 \\
(-0.43)\end{array}$ & $\begin{array}{l}0.51 \\
(4.56)\end{array}$ & $\begin{array}{l}0.41 \\
(1.19)\end{array}$ \\
\hline Social Services & $\begin{array}{l}-0.01 \\
(-0.01)\end{array}$ & $\begin{array}{c}-0.66 \\
(-0.95)\end{array}$ & $\begin{array}{l}0.26 \\
(1.48)\end{array}$ & $\begin{array}{l}0.37 \\
(1.35)\end{array}$ \\
\hline Public Administration & $\begin{array}{l}-0.10 \\
(-0.98)\end{array}$ & $\begin{array}{c}-0.48 \\
(-0.67)\end{array}$ & $\begin{array}{c}0.17 \\
(1.52)\end{array}$ & $\begin{array}{l}0.57 \\
(2.23)\end{array}$ \\
\hline Other Activities & $\begin{array}{l}0.50 \\
(3.98)\end{array}$ & $\begin{array}{c}-0.30 \\
(-0.43)\end{array}$ & $\begin{array}{l}0.65 \\
(4.86)\end{array}$ & $\begin{array}{l}0.82 \\
(3.34)\end{array}$ \\
\hline Occupations2 digits & Yes & Yes & No & No \\
\hline Occupations 3 digits & No & No & Yes & Yes \\
\hline Adjusted $R^{2}$ & 0.3468 & 0.3781 & 0.4057 & 0.4571 \\
\hline Number of Observations & 7087 & 3085 & 7087 & 3085 \\
\hline
\end{tabular}

Between parentheses are the $t$-statistics for each coefficient. All regressions have robust standard errors estimations All estimations are weighted by the individual weight available in the database. 
Table 7: Estimation Results, 1998.

\begin{tabular}{|c|c|c|c|c|}
\hline & $\begin{array}{c}\text { Men } \\
(1)\end{array}$ & $\begin{array}{c}\text { Women } \\
\text { (2) }\end{array}$ & $\begin{array}{c}\text { Men } \\
(3)\end{array}$ & $\begin{array}{c}\text { Women } \\
(4)\end{array}$ \\
\hline Intercept & $\begin{array}{l}-1.78 \\
(-52.83)\end{array}$ & $\begin{array}{l}-1.72 \\
(-35.25)\end{array}$ & $\begin{array}{c}-0.45 \\
(-6.43)\end{array}$ & $\begin{array}{c}-0.60 \\
(-1.63)\end{array}$ \\
\hline Age & $\begin{array}{c}0.07 \\
(40.32)\end{array}$ & $\begin{array}{c}0.06 \\
(23.79)\end{array}$ & $\begin{array}{c}0.06 \\
(34.23)\end{array}$ & $\begin{array}{c}0.05 \\
(20.67)\end{array}$ \\
\hline Age Squared & $\begin{array}{c}-0.00 \\
(-31.77)\end{array}$ & $\begin{array}{c}-0.00 \\
(-17.10)\end{array}$ & $\begin{array}{c}-0.00 \\
(-27.07)\end{array}$ & $\begin{array}{c}-0.00 \\
(-15.09)\end{array}$ \\
\hline South & $\begin{array}{l}-0.08 \\
(-10.11)\end{array}$ & $\begin{array}{l}-0.09 \\
(-17.10)\end{array}$ & $\begin{array}{l}-0.08 \\
(-10.41)\end{array}$ & $\begin{array}{l}-0.10 \\
(-10.08)\end{array}$ \\
\hline North & $\begin{array}{c}-0.26 \\
(-21 ; 64)\end{array}$ & $\begin{array}{l}-0.26 \\
(-8.72)\end{array}$ & $\begin{array}{l}-0.26 \\
(-22.11)\end{array}$ & $\begin{array}{l}-0.27 \\
(-19.18)\end{array}$ \\
\hline Northeast & $\begin{array}{l}-0.43 \\
(-57.64)\end{array}$ & $\begin{array}{l}-0.50 \\
(-17.79)\end{array}$ & $\begin{array}{l}-0.42 \\
(-58.18)\end{array}$ & $\begin{array}{l}-0.48 \\
(-53.59)\end{array}$ \\
\hline Center & $\begin{array}{l}-0.09 \\
(-8.65)\end{array}$ & $\begin{array}{l}-0.12 \\
(-53.54)\end{array}$ & $\begin{array}{c}-0.09 \\
(-8.87)\end{array}$ & $\begin{array}{l}-0.12 \\
(-10.33)\end{array}$ \\
\hline Education 1 & $\begin{array}{c}0.25 \\
(25.13)\end{array}$ & $\begin{array}{c}0.20 \\
(12.85)\end{array}$ & $\begin{array}{c}0.20 \\
(20.61)\end{array}$ & $\begin{array}{c}0.16 \\
(10.78)\end{array}$ \\
\hline Education 2 & $\begin{array}{c}0.49 \\
(45.02)\end{array}$ & $\begin{array}{c}0.40 \\
(24.30)\end{array}$ & $\begin{array}{c}0.38 \\
(35.44)\end{array}$ & $\begin{array}{c}0.33 \\
(20.47)\end{array}$ \\
\hline Education 3 & $\begin{array}{c}0.80 \\
(64.65)\end{array}$ & $\begin{array}{c}0.69 \\
(37.85)\end{array}$ & $\begin{array}{c}0.64 \\
(51.19)\end{array}$ & $\begin{array}{c}0.57 \\
(31.81)\end{array}$ \\
\hline Education 4 & $\begin{array}{c}1.46 \\
(86.54)\end{array}$ & $\begin{array}{l}1.32 \\
(62.86)\end{array}$ & $\begin{array}{l}1.12 \\
(63.92)\end{array}$ & $\begin{array}{c}1.03 \\
(48.04)\end{array}$ \\
\hline Transformation Industry & $\begin{array}{l}0.21 \\
(7.94)\end{array}$ & $\begin{array}{c}0.11 \\
(1.21)\end{array}$ & $\begin{array}{c}0.16 \\
(7.66)\end{array}$ & $\begin{array}{l}0.20 \\
(4.42)\end{array}$ \\
\hline Construction & $\begin{array}{l}0.11 \\
(4.00)\end{array}$ & $\begin{array}{l}0.23 \\
(2.27)\end{array}$ & $\begin{array}{c}0.09 \\
(4.13)\end{array}$ & $\begin{array}{l}0.34 \\
(5.94)\end{array}$ \\
\hline General Industry & $\begin{array}{c}0.28 \\
(8.74)\end{array}$ & $\begin{array}{c}0.22 \\
(2.15)\end{array}$ & $\begin{array}{c}0.31 \\
(10.60)\end{array}$ & $\begin{array}{c}0.53 \\
(8.26)\end{array}$ \\
\hline Commerce & $\begin{array}{c}0.12 \\
(4.30)\end{array}$ & $\begin{array}{c}0.09 \\
(1.01)\end{array}$ & $\begin{array}{l}0.10 \\
(4.34)\end{array}$ & $\begin{array}{c}0.19 \\
(4.04)\end{array}$ \\
\hline Services & $\begin{array}{l}0.10 \\
(3.74)\end{array}$ & $\begin{array}{c}-0.02 \\
(-0.20)\end{array}$ & $\begin{array}{c}-0.03 \\
(-1.22)\end{array}$ & $\begin{array}{c}0.09 \\
(1.98)\end{array}$ \\
\hline Transportation & $\begin{array}{c}0.38 \\
(13.67)\end{array}$ & $\begin{array}{c}0.33 \\
(3 ; 38)\end{array}$ & $\begin{array}{c}0.25 \\
(11.07)\end{array}$ & $\begin{array}{l}0.35 \\
(6.27)\end{array}$ \\
\hline Social Services & $\begin{array}{c}0.10 \\
(3.50)\end{array}$ & $\begin{array}{c}-0.01 \\
(-0.07)\end{array}$ & $\begin{array}{c}0.10 \\
(3.82)\end{array}$ & $\begin{array}{l}0.19 \\
(4.33)\end{array}$ \\
\hline Public Administration & $\begin{array}{c}0.34 \\
(12.31)\end{array}$ & $\begin{array}{c}0.24 \\
(2.53)\end{array}$ & $\begin{array}{c}0.07 \\
(3.07)\end{array}$ & $\begin{array}{l}0.30 \\
(6.48)\end{array}$ \\
\hline Other Activities & $\begin{array}{l}0.25 \\
(9.23)\end{array}$ & $\begin{array}{l}0.26 \\
(2.79)\end{array}$ & $\begin{array}{l}0.16 \\
(7.23)\end{array}$ & $\begin{array}{l}0.34 \\
(7.25)\end{array}$ \\
\hline Occupations 2 digits & Yes & Yes & No & No \\
\hline Occupations 3 digits & No & No & Yes & Yes \\
\hline Adjusted $R_{2}$ & 0.5177 & 0.4994 & 0.57 & 0.5627 \\
\hline Number of Observations & 70440 & 43320 & 70440 & 43320 \\
\hline
\end{tabular}

Between parentheses are the $t$-statistics for each coefficient. All regressions have robust standard errors estimations All estimations are weighted by the individual weight available in the database. 


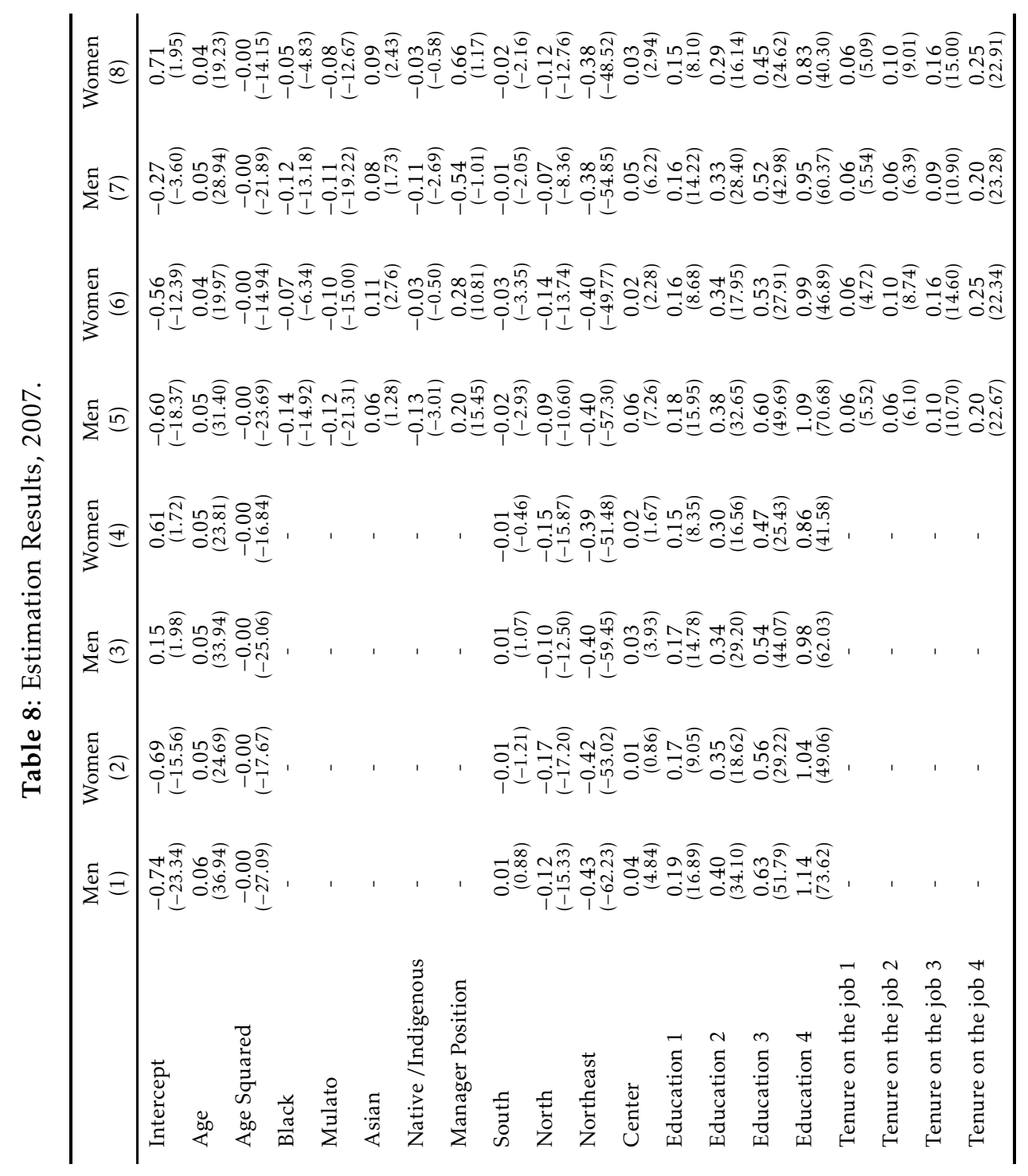




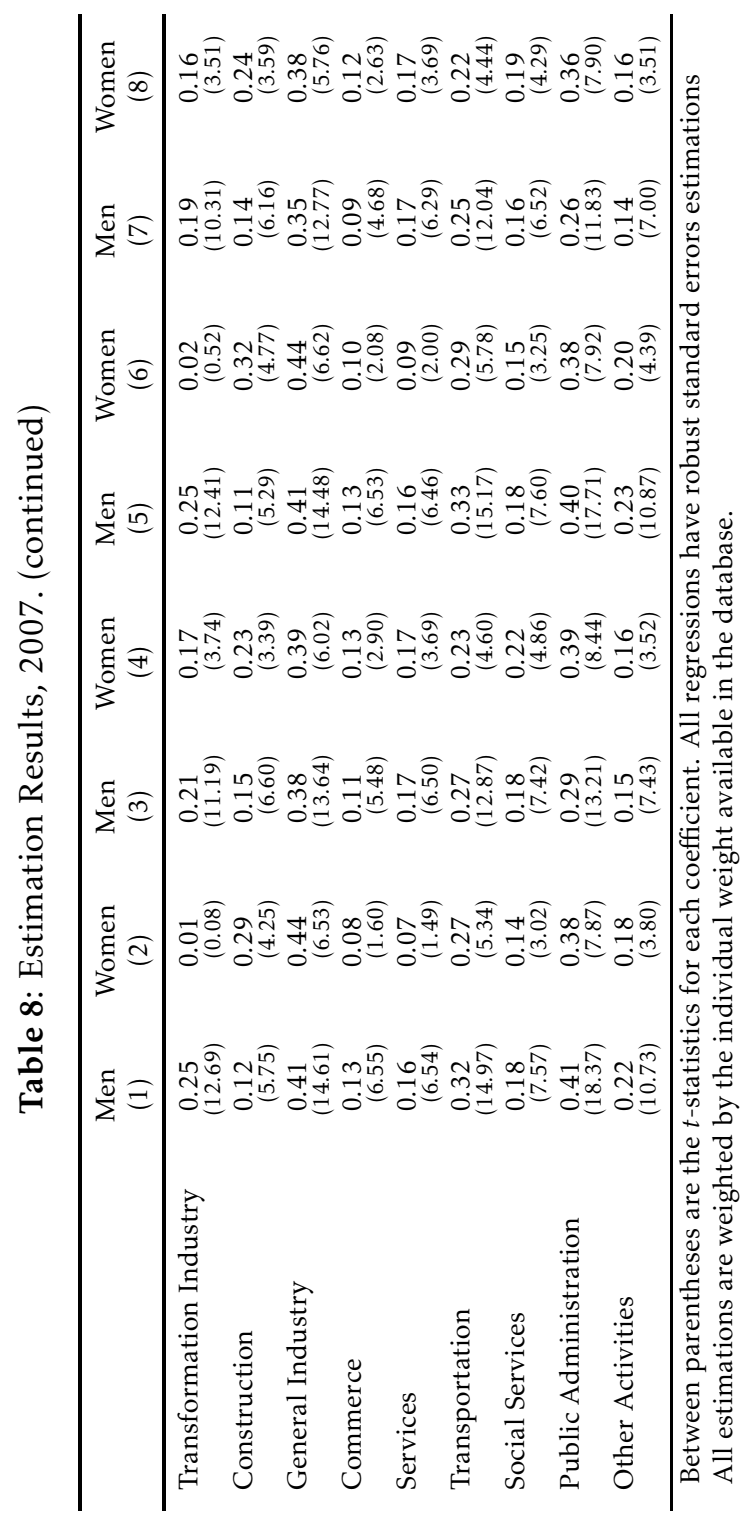


Education dummies are the third control variables. For both men and women, wage increases with education. The impact of education is consistently greater for males than females throughout the categories and years. ${ }^{21}$

Finally, there is the occupation and industry impact on wages. We used two different types of classification for occupational choice. The usual and more appropriate one has a three-digit classification. Because it has too many groups, its analysis is excessively intricate. Therefore, for each year, we run a regression with occupational choice divided on two-digit and three-digit classifications. ${ }^{22}$ Columns (1) and (2) in Tables 5 through 7 display the former results and columns (3) and (4) of each table display the latter ones. Table 8, regarding 2007 data, has more columns, to include controls that were not available on previous years. Therefore, in Table 8 , the controls for occupation in columns (1), (2), (5) and (6) have a two digit classification and the other columns have a three digit classification. The more restricted classification of occupation interferes with the results of other variables. This is true for the results by industry, which is our next focus. ${ }^{23}$

Industry indicators are fewer, and we can see a tendency in the estimated coefficients. For males, the industrial sector pays more. For females, public administration confers more wage benefits than other occupations. These effects may be a combination of discrimination with a gender comparative advantage. Bergmann (1974) established a model to test the profitability function of occupation discrimination against its sociological purpose. She concluded that the latter may have a bigger influence on decision-makers. Using her model, we can conclude that activities with a greater social impact appear to suit women better, and that those where technical appeal is stronger suit men better. Therefore, recruiters prefer to place individuals in jobs associated with the characteristics of their gender (Hochschild 2003).

It is also important to control for diverse factors (included in the regressions presented here) to really observe effects that are conditional on other individual characteristics. For example, Table 3 compares gender wage differentials by industries without other controls. In that table, we observe that men earn higher wages than women in almost all industries. Observing Table 5 , columns (1) and (2) the first table with regression results, we see that, with poorer controls for occupations, the results stay the same. In other words, in certain industries, women are shown to receive lower pay than men when controls on occupation are poor. However, when we use occupations discriminated on three digits, the results change. For example, the "Transformation Industry," which showed a significant premium for males in Table 3 and on columns (1) and (2) of Table 5, has a bigger premium for females than males

\footnotetext{
agribusiness and the lumber industry took root.

${ }^{21}$ The same result was found using quantile estimation in Santos \& Ribeiro (2006).

${ }^{22}$ The estimated coefficients for this category are not in the tables, since they would take too much space. However, the results show that women are better remunerated in occupations where they are a very small minority, such as the military, and that they have a smaller wage premium than men in categories where they are numerous, such as technical occupations. Full results are available upon request.

${ }^{23}$ We also tried to estimate the impact of occupational choice on the gender wage gap. However, for the chosen years, the result is very unstable, with anywhere from $13 \%$ to $164 \%$ of the gap being explained by occupational choice. The explanation for these results so dissimilar is probably related to different sample compositions of PNAD along years. Future research should be conducted using a different database - one suggestion is the Decennial Census data - that permits a more consistent analysis of this effect.
} 
when better controls for occupation are in place.

For the 2007 data, we also created an additional model that includes race, a manager indicator and tenure on the job. The results are presented in columns (5) and (6) of Table 8. The variables analyzed earlier maintain their impact and significance. The included variables have significance for both men and women. The race impact demonstrates that Asian individuals earn higher wages than other races. Tenure on the job is another variable that consistently increases wages. However, in this case, the impact on female wages is greater than on male wages. Staying for more than 5 years in the same job has a positive impact on male and female wages; however, the impact on women's wages is 5 percent greater. ${ }^{24}$ This result is very interesting because it may reflect women's need to use their labor participation constancy to signal that they wish to continue in their jobs. Intermittency is one special characteristic of the labor market for women. For many years, women used to work only before getting married or, in some cases, until having the first child. However, today, both maternity leave benefits and the degree of effort women put into their education make remaining in the labor market after having a family possible. Even so, employers may doubt this intention and only reward those women who are able to demonstrate their constancy. This effect appears to be the same as the one posed by Spence for education (Spence 1973).

Finally, the "manager effect" has no significant impact for either men or women. Our result is similar to that of Budig \& England (2001), who did not find a significant effect of the variable authority on wages.

These results point to better conditions for females in the Brazilian labor market; however, they are by no means conclusive. One way to discover better answers is to use the Oaxaca decomposition, as shown in equation (4). Using the female characteristics and inputting them both on male and on female estimated coefficients, we can compare a woman being paid "like a man" to one paid "like a woman." If the individual maintains all of her characteristics but is paid differently, we have room to call this discrimination. Table 9 shows these results for each of the four analyzed years.

For each year, we used the estimated coefficients in equations (2) and (3) to estimate the predicted hourly wage for the women's sample. Table 9 reports the results without logarithmics, i.e., each value represents the predicted wage for women considering their own characteristics inputted on both men's estimated coefficients and women's estimated coefficients. We report the difference in market remuneration for men and women by a percentage. Rows displaying the "difference" represent the percentage of women who earn less than men. It is important to stress that this percentage refers only to the unexplained wage difference between genders; the portion of the difference explained by the variables that are controlled is not in these results. All of the predicted values were tested and were significantly different. We observe that men earned greater wages than women in the past and continue to do so. However, the gap was 33 percent in 1978, but dropped to just above than 16 percent in 2007. For 2007, we present two estimations: one with the equation that retains the controls available for other years (Tables 5 to 8), and the other with the additional controls of race, tenure and authority (Table 9). We note that with better controls, the gender wage gap appears smaller.

${ }^{24}$ This difference is statistically significant at the 5 percent level. 
Table 9: Oaxaca Results for the Unexplained Portion of the Gender Wage Gap.

\begin{tabular}{lc}
\hline & Estimated Average Hourly Wage \\
\hline & 1978 \\
As men & 14.51 \\
As women & 9.71 \\
Difference & $-33.05 \%$ \\
\hline \multicolumn{2}{c}{1988} \\
\hline As men & 261.57 \\
As women & 201.35 \\
Difference & $-23.02 \%$ \\
\hline \multicolumn{2}{c}{1998} \\
\hline As men & 1.9 \\
As women & 1.55 \\
Difference & $-18.42 \%$ \\
\hline \multicolumn{2}{c}{} \\
\hline As men & 3.97 \\
As women & 3.22 \\
Difference & $-16.19 \%$ \\
\hline \multicolumn{2}{c}{2007 with more controls } \\
\hline As men & 3.96 \\
As women & 3.35 \\
Difference & $-15.40 \%$ \\
\hline
\end{tabular}

A final comment concerning these results is that we conclude that the gender wage gap in Brazil is decreasing. However, this methodology cannot address all factors that may affect the gap. Since we use a control for occupations, and the previous literature shows some evidence of gender segregation in some occupations, we might be underestimating this difference.

\section{Conclusion}

As in other countries, the labor market conditions of women in Brazil are improving. Labor regulation provides both the positive effect of guaranteeing the presence of an adult in households with children, mainly through paid maternity leave, and the negative effect of increasing informal hiring. In addition to regulation, discrimination and different preferences in hiring explain part of the gender wage gap.

The present analysis of the Brazilian labor market shows that there is gender segregation in occupations and industries; however, such segregation does not always negatively affect women's wages. For industries and occupations where women receive higher remuneration than men, we observe that women have higher education levels, indicating that their higher remuneration is due to individual characteristics. This result is compatible with that of Madalozzo \& Martins (2007), who used quantile regression to investigate the wage gap by conditional distribution.

Estimation results show different returns for all variables depending on gender. Generally, women are more poorly remunerated than men when controlling for individual characteristics. The Oaxaca decomposition reinforces 
this conclusion, showing that, when both have the same characteristics, men are better paid than women. This difference in pay is decreasing but was still a significant 15.4 percent, on average, in 2007. Compared with other studies, the present study improves the quantification of this wage gap, showing that the trend of a decreasing gap remains, but is losing pace overtime. Future research on this area should consider investigating more deeply the affect of occupation choice on the gender wage gap. For instance, Scorzafave \& Pazello (2007) demonstrated the impact of several variables on the wage gap, but also did not focus on occupation choice. Analyzing of the impact of occupational choice on the gender wage gap is a promising way to understand the evolution of the female labor market.

Since women's participation in the labor market is a decision that is endogenous to remuneration of their work, this persistent difference when compared to men is a potential disincentive to better education and constancy in the market. Both conditions are dangerous to the economy: education by perpetuating income inequality in Brazil, Bourguignon et al. (2007), and constancy by appealing to women to leave the labor market more often because of the opportunity costs of maintaining "two shifts." Researchers and policymakers should pay attention to these effects and provide viable alternatives to ensure women's entrance into the labor market.

\section{Bibliography}

Albrecht, J., Björklund, A. \& Vroman, S. (2003), 'Is there a glass ceiling in sweden?', Journal of Labor Economics 21, 145-177.

Alvarez, L., Dhyne, E., Hoeberichts, M., Kwapil, C., Le Bihan, H., Lünnemann, P., Martins, F., Sabbatini, R., Stahl, H., Vermeulen, P. \& Vilmunen, J. (2006), 'Sticky prices in the euro area: A summary of new micro-evidence', Journal of the European Economic Association 4.

Batista, N. \& Cacciamali, M. (2009), 'Diferencial de salários entre homens e mulheres segundo a condição de migração', Revista Brasileira de Estudos de População 26, 97-115.

Bayard, K., Hellerstein, J. \& Neumark, D. (2003), 'New evidence on sex segregation and sex differences in wages from matched employee-employer data', Journal of Labor Economics 21, 887-922.

Bergmann, B. (1974), 'Occupational segregation, wages and profits when employers discriminate by race or sex', Eastern Economic Journal 1, 103-110.

Bergmann, B. (2008), Basic income grants of the welfare state: Which better promotes gender equality?, Technical report, Basic Income Studies.

Bertrand, M. \& Hallock, K. (2001), 'The gender gap in top corporate jobs', Industrial and Labor Relations Review 55, 3-21.

Blau, F., Ferber, M. \& Winkler, A. (2006), The economics of women, men, and work, Pearson Prentice Hall.

Blau, F. \& Kahn, L. (1997), 'Swimming upstream: Trends in the gender wage differential in the 1980s', Journal of Labor Economics 15, 1-42. 
Bourguignon, F., Ferreira, F. \& Menéndez, M. (2007), 'Inequality of opportunity in brazil', Review of Income \& Wealth 53, 585-618.

Bruschini, C. (1989), Tendências da força de trabalho feminina brasileira nos anos setenta e oitenta: Algumas comparações regionais, Technical report, Fundação Carlos Chagas.

Bruschini, C. (1998), Trabalho das mulheres no brasil: Continuidades e mudanças no período 1985-1995, Technical report, Fundação Carlos Chagas.

Bryan, M. \& Sanz, A. (2007), Does housework lower wages and why? evidence for britain, Technical report, University of Oxford.

Bucheli, M. \& Sanroman, G. (2005), 'Salarios femeninos en el uruguay: Existe un techo de cristal?', Revista de Economia 12, 63-88.

Budig, M. \& England, P. (2001), 'The wage penalty for motherhood', American Sociological Review 66, 204-225.

Deloach, S. \& Hoffman, A. (2002), 'Russia's second shift: Is housework hurting women's wages?', Atlantic Economic Journal 30, 422-433.

Easterlin, R. (1995), 'Preferences and prices in choice of career: The switch to business, 1972-87', Journal of Economic Behavior and Organization 27, 1-34.

Edwards, R. (2006), 'Maternity leave and the evidence for compensating wage differentials in australia.', Economic Record 82, 281-297.

Ferber, M. (2003), A feminist critique of the neoclassical theory of the family, in 'Women, famiy, and work: Writings on the economics of gender', Blackwell.

Folbre, N. (1994), Who Pays for the Kids? Gender and the Structures of Constraint, Routledge.

Galarza, J., Medina, R. \& Díaz, L. (2006), Evolución de lãs diferencias salariales de género en seis países de américa latina, Technical report, Banco Interamericano de Desarrollo.

Garcia, L., Ñopo, H. \& Salardi, P. (2009), Gender and racial wage gaps in brazil 1996-2006: Evidence using a matching comparisions approach, Technical report, Inter-American Development Bank Working Paper.

Giuberti, A. C. \& Menezes-Filho, N. (2005), 'Discriminação de rendimentos por gênero: Uma comparação entre o brasil e os estados unidos', Economia Aplicada 9, 369-383.

Gupta, S. \& Ash, M. (2008), 'Whose money, whose time? a nonparametric approach to modeling time spent on housework in the united states.', Feminist Economics 14, 93-120.

Hersch, J. \& Stratton, L. (1994), 'Housework, wages, and the division of housework time for employed spouses', American Economic Review 84, 120 126.

Hersch, J. \& Stratton, L. (2002), 'Housework and wages', Journal of Human Resources 37, 217-229. 
Hochschild, A. (2003), The second shift, Technical report, Penguin Group.

Jacinto, P. (2005), 'Diferenciais de salaries por gênero na indústria avícola da região sul do brasil: uma análise com micro dados', Revista de Economia e Sociologia Rural 43, 529-555.

Kaufman, B. \& Hotchkiss, J. (2003), The economics of labor markets, Thomson South-Western.

Lundberg, S. (2008), Gender and household decision-making, in 'Frontiers in the Economics of Gender', Routledge.

Macpherson, D. \& Hirsch, B. (1995), 'Wages and gender composition: Why do women's jobs pay less?', Journal of Labor Economics 2, 426-471.

Madalozzo, R. C., Martins, S. R. \& Shiratori, L. (2008), Participação no mercado de trabalho e no trabalho doméstico: Homens e mulheres têm condições iguais?, Technical report, IBMEC.

Madalozzo, R. \& Martins, S. (2007), 'Gender wage gaps: comparing the 80s, 90s and 00s in brazil', Revista de Economia e Administração 6, 141-156.

Miller, P. (2009), 'The gender pay gap in the us: Does sector make a difference?', Journal of Labor Research 30, 51-74.

Mincer, J. (1995), Labor force participation of married women: A study of labor supply, in 'Gender and economics', Aldershot.

Moe, K. (2003), Women, family, and work: Writings on the economics of gender, Blackwell Publishing.

Oaxaca, R. (1973), 'Male-female wage differentials in urban labor markets', International Economic Review 14, 693-709.

Olivetti, C. \& Petrongolo, B. (2008), 'Unequal pay or unequal employment? a cross-country analysis of gender gaps', Journal of Labor Economics 26, 621654.

Patterson, M. \& Engelberg, L. (1978), Women in male-dominated professions, in 'Women working: Theories and facts in perspective', Mayfield.

Santos, R. \& Ribeiro, E. (2006), Diferenciais de rendimentos entre homens e mulheres no brasil revisitado: Explorando o "teto de vidro", Technical report, UFRJ.

Scorzafave, L. \& Pazello, E. (2007), 'Using normalized equations to solve the indetermination problem in the oaxaca-blinder decomposition: An application to the gender wage gap in brazil', Revista Brasileira de Economia 61, 535548 .

Spence, A. M. (1973), 'Job market signaling', Quarterly Journal of Economics 87, 355-374.

Waldfogel, J. (1998), 'Understanding the "family gap" in pay for women with children', Journal of Economic Perspectives 12, 137-157. 